\title{
ESTIMATION OF TOTAL PHENOL IN SOME MEDICINAL PLANTS OF MARATHWADA REGION IN MAHARASHTRA
}

\author{
Kadam V.B.*, Sonawane V.B., Khandare K.R ${ }^{1}$.KadamU.B. ${ }^{2}$ \\ * P.G.Dept. of Botany and Res. Centre, K.T.H.M.College, Nashik - 422002 \\ ${ }^{1}$ Department of Botany, M.V.P.Samaj's , Science College, Satana (Nashik) \\ ${ }^{2}$ P.G.Dept.of Chemistry and Res. Centre, M.S.G.College, Malegaon - 423203
}

*Corresponding author's Email ID: drvbkadam@yahoo.com

\begin{abstract}
An attempt has been made here to investigate occurrence of total phenol in the leaves, bark and wood of Butea monosperma Lam, Madhucaindica Gmel, Mimusopselengi Linn and Syzygiumcumini Linn. are medicinally important plants of Marathwada region in Maharashtra. Comparative account of total phenol content of leaves ,bark and wood of four species revealed that, Madhucaindica were rich (range 2.156 to $4.410 \mathrm{mg} / \mathrm{g}$ dry wt. ) than Butea monosperma (range 1.987 to $4.138 \mathrm{mg} / \mathrm{g}$ dry wt.), Mimusopselengi (range 2.601 to $3.438 \mathrm{mg} / \mathrm{g}$ dry wt.) and Syzygiumcumini (range 1.621 to $3.330 \mathrm{mg} / \mathrm{g}$ dry wt. ) in all seasons.

Key words: Total Phenol, Medicinal Plants, Marathwada region.
\end{abstract}

\section{INTRODUCTION}

There are many phenolic compounds which have gained importance as plant growth regulators in recent years. The phenolic compounds have been found to occur in micro-organisms, pteridophytes, gymnosperms and angiosperms . Earlier, most of the phenolic compounds are believed to be inhibitory in nature. From careful studies with the different concentrations of of phenolic compounds it followed that many of them could stimulate physiological and biochemical processes at very low concentration .

Butea monosperma (Lam.) is an indispensable tree. Tribal's use its flowers and young fruits. The plant is used in Ayurvedic, Unani and Siddha medicine for various ailments. Almost all the parts of the plant namely root, leaves, fruit, stem bark, flowers, gum young branches are used as medicine, food, fibre and for other miscellaneous purposes such as fish poison, dye, fodder, utensils, etc. ${ }^{1}$. The bark is reported to possess antitumor and antiulcer activities. The root bark is used as an aphrodisiac, analgesic and antihelmintic whereas the leaves possess antimicrobial properties ${ }^{2}$.

Madhucaindica is medicinally and commercially useful. The plant parts like stem bark, corolla lobes, seeds and seed oil are used in diabetes, burns, scalds, bronchitis, rheumatism, cough, piles, galactagogue skin diseases, tonsillitis, stomach-ache, aphrodisiac and respiratory diseases and have laxative, insecticidal and pesticidal properties $^{3}$. The methanolic extracts of flowers, leaves, stem and stem bark of $M$. longifolia have been reported to possess antibacterial activity against Bacillus anthracis, $B$. pumilus, B. subtilis, Salmonella paratyph and Vihriocholerae ${ }^{4}$.

Mimusopselengi belongs to the family Sapotaceae. It is an evergreen tree, 5-8 m tall and is cultivated throughout our country as an ornamental tree. The bark is used as a gargle for odontopathy, ulitis and ulemorrhagia. Fruits are used as astringent, coolant and anthelmintic. The tender stems are used as tooth brushes, and in cystorrhea, diarrhea and dysentery ${ }^{5}$. The seeds are used in constipation ${ }^{6}$. Different solvent extracts of bark, fruits (fleshy portion) and leaves of Mimusopselengi were screened for their antibacterial and antifungal activities against some pathogenic bacteria and fungi ${ }^{7}$.

Syzygiumcumini (Linn) Skeel showed an antimicrobial effect against enteric bacteria ${ }^{8}$. According to Ayurveda, its bark is acrid, sweet, digestive, and in good for sore throat, asthma, dysentery, blood impurities and to cure ulcers ${ }^{9}$.Syzygiumcumini is a medicinal plant, whose parts were pharmacologically proved to possess hypoglycemic, antibacterial, anti-HIV activity and anti-diarrhea effects ${ }^{10}$. An attempt is made to investigate the occurrence and seasonal variations of phenol in four medicinal important taxa (Butea monosperma Lam, Madhucaindica Gmel, Mimusopselengi Linn and Syzygiumcumini Linn.) of Marathwada region of Maharashtra.

\section{MATERIALS AND METHODS}

The plant material of Butea monosperma Lam, Madhucaindica Gmel, Mimusopselengi Linn and Syzygiumcumini Linn were collected from different places of Marathwada region in Maharashtra during different seasons viz. summer (April), monsoon (June ) and winter ( November). The ethanol extractable phenolic compounds were estimated by folin method ${ }^{11}$.

Phenolic compounds were extracted by grinding $50 \mathrm{mg}$ ( dry weight) sample of tissue using a chilled pastle and mortar with an aliquot of chilled $80 \%(\mathrm{~V} / \mathrm{V}$ ) ethanol. The homogenate was centrifuged at $13000 \mathrm{rpm}$ for 15 minutes. The supernatant was collected and residue pellet was extracted twice more as above. The supernatant of all three extractions was polled and volume made up to $25 \mathrm{ml}$ with $80 \%$ ethanol. A suitable aliquot of the ethanolic extract was diluted with distilled water to $8.5 \mathrm{ml}$ and after adding $0.5 \mathrm{ml}$ of Folin phenol reagent. The content were mixed well , three minutes latter, $1 \mathrm{ml}$ of saturated sodium carbonate solution ( $1 \mathrm{gm} / 3 \mathrm{ml}$ ) of distilled water was 
added and the mixture shaken thoroughly. Color was allow to develop for 60 minutes and then read at 725 $\mathrm{nm}$ in spectrophotometer. Standard curved was prepared using chlorogenic acid/tannic acid/Gallic acid and all the concentrations were expressed in terms of $\mathrm{mg} / \mathrm{g}$ of this compound.

\section{RESULTS AND DISCUSSION}

The concentration total phenol of Butea monosperma was ranging from 3.64 to $3.81 \mathrm{mg} / \mathrm{g}$ dry wt. in leaves. The total phenol content of bark of Butea monosperma exhibited maximum levels in summer ( $4.13 \mathrm{mg} / \mathrm{g}$ dry wt. ) over that of monsoon $(3.92 \mathrm{mg} / \mathrm{g}$ dry wt.) and winter $(4.01 \mathrm{mg} / \mathrm{g}$ dry wt.) (Table 1). The total phenol content of wood of Butea monosperma was not significantly different (as it ranges between 1.98 to $2.12 \mathrm{mg} / \mathrm{g}$ dry wt. ) from other parts during various seasons. The repeated measuring of total phenol continuously for two years proved that there was no much difference in their different parts. The total phenol content of leaves of Madhucaindica was raised in summer ( $4.31 \mathrm{mg} / \mathrm{g}$ dry wt. $)$ over that of monsoon ( $4.13 \mathrm{mg} / \mathrm{g}$ dry wt. ) and winter ( $4.24 \mathrm{mg} / \mathrm{g}$ dry wt.). The total phenol content in bark of Madhucaindica was highest in summer ( $4.41 \mathrm{mg} / \mathrm{g}$ dry wt. ) over that of winter ( $4.33 \mathrm{mg} / \mathrm{g}$ dry wt. ) and monsoon ( $4.27 \mathrm{mg} / \mathrm{g}$ dry wt. ) . The total phenol content of wood of Madhucaindica was raised in summer ( $2.36 \mathrm{mg} / \mathrm{g}$ dry wt. ) over that of winter ( $2.28 \mathrm{mg} / \mathrm{g}$ dry wt. ) and monsoon ( $2.15 \mathrm{mg} / \mathrm{g}$ dry wt. ).
The total phenol content of leaves of Mimusopselengi was higher in summer ( $3.23 \mathrm{mg} / \mathrm{g}$ dry wt. ) over that of winter ( $3.17 \mathrm{mg} / \mathrm{g}$ dry wt. ) and monsoon ( $3.04 \mathrm{mg} / \mathrm{g}$ dry wt. ). Total phenol content of bark of Mimusopselengi ranged from 3.31 to $3.43 \mathrm{mg} / \mathrm{g}$ dry wt. . Comparatively wood of Mimusopselengi exhibited low concentration of phenol content ( 2.60 to $2.92 \mathrm{mg} / \mathrm{g}$ dry wt. ). The total phenol content of leaves of Syzygiumcumini was higher in summer ( $2.94 \mathrm{mg} / \mathrm{g}$ dry wt.) over that of winter $(2.87 \mathrm{mg}$ / g dry wt. ) and monsoon ( $2.83 \mathrm{mg} / \mathrm{g}$ dry wt. ). Total phenol content of bark of Syzygiumcumini ranged from 3.23 to $3.33 \mathrm{mg} / \mathrm{g}$ dry wt. . Comparatively wood of Syzygiumcumini exhibited low concentration of phenol content ( 1.62 to $1.73 \mathrm{mg} / \mathrm{g}$ dry wt.).

The total phenol content of leaves of Madhucaindica was higher ( ranged from 4.13 to $4.31 \mathrm{mg} / \mathrm{g}$ dry wt.) than Syzygiumcumini( ranged from 2.83 to $2.94 \mathrm{mg} / \mathrm{g}$ dry wt.) ,Mimusopselengi (ranged from 3.04 to $3.23 \mathrm{mg} / \mathrm{g}$ dry wt. ) and Butea monosperma (ranged from 3.64 to $3.81 \mathrm{mg} / \mathrm{g}$ dry wt.). Comparatively bark of Madhucaindica was higher (ranged from 4.27 to $4.41 \mathrm{mg} / \mathrm{g}$ dry wt.) than Syzygiumcumini( ranged from 3.23 to $3.33 \mathrm{mg} / \mathrm{g}$ dry wt.), Mimusopselengi (ranged from 3.31 to $3.43 \mathrm{mg} / \mathrm{g}$ dry wt.) and Butea monosperma(ranged from 3.92 to $4.13 \mathrm{mg} / \mathrm{g}$ dry wt.). Comparatively phenol content of wood of Mimusopselengi was higher ( ranged from 2.60 to $2.92 \mathrm{mg}$ / g dry wt.) than Syzygiumcumini ( ranged from 1.62 to 1.74 $\mathrm{mg} / \mathrm{g}$ dry wt.), Madhucaindica (ranged from 2.15 to $2.36 \mathrm{mg}$ / g dry wt.) and Butea monosperma (ranged from 1.98 to 2.12 $\mathrm{mg} / \mathrm{g}$ dry wt.).

Table 1: Seasonal variations of total phenol content of different plant parts of Butea monosperma Lam, Madhucaindica Gmel, Mimusopselengi Linn and Syzygiumcumini Linn.

\begin{tabular}{|c|c|c|c|c|c|}
\hline \multirow[b]{2}{*}{ Plant parts } & \multirow[b]{2}{*}{ Season } & \multicolumn{4}{|c|}{ TOTAL PHENOL (Mg / g dry wt.) } \\
\hline & & Buteamonosperma & Madhucaindica & Mimusopselengi & Syzygiumcumini \\
\hline \multirow[t]{3}{*}{ Leaves } & Summer & 3.812 & 4.319 & 3.235 & 2.945 \\
\hline & Monsoon & 3.643 & 4.135 & 3.045 & 2.835 \\
\hline & Winter & 3.714 & 4.245 & 3.175 & 2.875 \\
\hline \multirow{3}{*}{ Wood } & Summer & 2.122 & 2.367 & 2.601 & 1.734 \\
\hline & Monsoon & 1.987 & 2.156 & 2.675 & 1.621 \\
\hline & Winter & 2.066 & 2.289 & 2.925 & 1.675 \\
\hline \multirow{3}{*}{ Bark } & Summer & 4.138 & 4.410 & 3.438 & 3.330 \\
\hline & Monsoon & 3.920 & 4.274 & 3.312 & 3.232 \\
\hline & Winter & 4.017 & 4.334 & 3.382 & 3.278 \\
\hline
\end{tabular}

\section{REFERENCES}

1. Burli and Khade AB: A Comprehensive review on Buteamonosperma (Lam.) Kountze Pharmaconognosy Reviews, 2007, Vol 1, Issue 2.

2. Kasture VS, Deshmukh VK, Chopade CT, Anticonvulsive activity of ButeaMonosperma flowers in laboratory animals. Pharmacol.Behav., 2002, 72: 965 -72.

3. Kirtikar KR, Basu BD, Indian Medicinal Plants. Vol II (Periodical Experts, New Delhi), 1975, 1052-53.

4. Trivedi, V.B., Kazmi, S.M. and Kazmi, S.N., Comparative bactericidal activity of two angiosperms. Bulletin of Botanical Society, University of Sagar, 1980, 27: 36

5. Tambe SS, Shailaja D, Ahire PP, Kadam VB, Biochemical evaluation of some medicinal plants of Marathwada region in Maharashtra. International J. of Pharma.Res. and Bio-Sci. 1, 2012, (4) : $185-194$.

6. Nair R, Chanda SV, Antibacterial activities of some medicinal plants of the western region of India. Turkish Journal of Biology, 2007, 31: 231-236
7. Abbas Ali, Abdul Mozid, Mst. SarminaYeasmin, AstaqMohal Khan and Abu Sayeed, An Evaluation of Antimicrobial Activities of MimusopselengiLinn.Research Journal of Agriculture and Biological Sciences, 2008, 4(6): 871-874.

8. Alanis AD, Calzada F, Cervanter JA, Torres,J, Ceballos,GM, AntibacterialProperties of some plants used in Mexican traditional medicine for the treatment of gastrointestinal disorders. J.Ethnopharmacol. 2005, 100: 153 - 157.

9. Kirtikar KR, Basu BD, Indian Medicinal Plants, Bishen SinghMahendra Pal Singh, Debra Dun, 1980, Vol. 1-4.

10. Kadam VB, Biochemical evaluation of three endangered medicinal taxa of SouthGujarat forest. Journal of Phytological Research, 2010, 13, (1) :85- 87

11. Swan T, Hillis WE, The phenolic estimation of Prunusdomestica J. Sci. Food. Agri., 1959, 10: 63-68 